\title{
Effects of sodium hyaluronate and carboxymethylcellulose membrane on collagen and fibroblast formation in bowel suture healing: experimental study in rats $^{1}$
}

\author{
Efeitos da membrana de hialuronato de sódio e carboximetilcelulose na formação de \\ colágeno e fibroblastos no processo de cicatrização de colorrafias: estudo \\ experimental em ratos
}

\section{Antônio Carlos Perez ${ }^{2}$, Delcio Matos ${ }^{3}$, Edna Frasson de Souza Montero ${ }^{4}$, Heitor Soares de Souza ${ }^{5}$, Fábio Colagrossi Paes Barbosa ${ }^{6}$, Fabio Saad ${ }^{6}$, Nelson Dip ${ }^{7}$}

1. Work performed in the Postgraduate Program in Surgical Gastroenterology, Federal University of São Paulo (UNIFESP).

2. Associate Professor, Federal University of Mato Grosso do Sul (UFMS).

3. Coordinator of the Postgraduate Program in Surgical Gastroenterology, UNIFESP.

4. Affiliated Professor of the Department of Surgery, UNIFESP.

5. Substitute Professor of the Department of General Surgery, UFMS.

6. Medical student, UFMS.

7. Medical resident in General Surgery, UFMS.

\begin{abstract}
Purpose: To analyze the effects of sodium hyaluronate and carboxymethylcellulose membrane on collagen and fibroblast formation in bowel suture healing in rats. Methods: 48 male Wistar rats, weighing 250 to 343g, were randomized into two groups: group I - bowel suture without applying a biologically absorbable membrane and group II - bowel suture with application of an absorbable membrane. The two groups were divided into subgroups of 3, 14 and 30 days of observation, with 8 rats in each subgroup. All were sacrificed after the end of the observation period. Results: No morbidity or mortality was observed during the experiment. The amounts of collagen in group I were $23.4 \%, 72.1 \%$ and $67.6 \%$ and in group II were $22.5 \%, 52.5 \%$ and $51.6 \%$, for the subgroups of 3, 14 and 30 days, respectively. Comparison between groups showed that the 14-day ( $\mathrm{p}=0.0013$ ) and 30-day ( $\mathrm{p}=0.0587$ ) subgroups had significant variance, with larger collagen zones in animals in which the membrane was not applied. However, with regard to fibroblasts, group I had 2\%, $13 \%$ and $8 \%$ and group II had 2\%, 10\% and 8\%, for the 3-day ( $\mathrm{p}=1.0)$, 14-day ( $\mathrm{p}=0.3184)$ and 30-day ( $\mathrm{p}=0.5995)$ subgroups, respectively, showing no significant variance. Conclusion: The use of the biologically absorbable membrane cause a decrease in collagen formation, while not altering the number of fibroblasts, in bowel suture healing in rats, without increased morbidity and mortality.
\end{abstract}

Key words: Carboxymethylcellulose. Colon. Healing. Rats.

\section{RESUMO}

Objetivo: Analisar os efeitos da membrana de hialuronato de sódio e carboximetilcelulose, na formação de colágeno e fibroblastos na colorrafia de ratos. Métodos: Foram utilizados 48 ratos machos da linhagem Wistar, com peso entre 250 e 343g, distribuídos em dois grupos: grupo I - colorrafia sem aplicação de membrana bioabsorvível e grupo II - colorrafia com aplicação de membrana bioabsorvível; tendo sido divididos em subgrupos de 3, 14 e 30 dias de observação, com 8 animais em cada um dos subgrupos, todos submetidos à eutanásia após o período correspondente. Resultados: Não foi observada morbimortalidade. A quantidade de colágeno no grupo I foi de 23,4\%, 72,1\% e 67,6\%; no grupo II 22,5\%, 52,5\% e 51,6\%, ambos os grupos nos 3, 14 e 30 dias, respectivamente, tendo na comparação intergrupos demonstrado que os subgrupos 
14 ( $p=0,0013)$ e 30 ( $p=0,0587)$ obtiveram variância significativa, apresentando zona de colágeno maior nos animais nos quais não se usou a membrana; entretanto, em relação à quantidade de fibroblastos, o grupo I obteve $2 \%, 13 \%$ e $8 \%$; o grupo II obteve $2 \%, 10 \%$ e $8 \%$, ambos os grupos nos $3(\mathrm{p}=1,0), 14$ ( $\mathrm{p}=0,3184)$ e 30 ( $p=0$,5995) dias, respectivamente, demonstrando não haver variância significativa. Conclusão: Autilização da membrana bioabsorvível determinou diminuição da formação de colágeno e não alterou o número de fibroblastos na cicatrização de colorrafias, sem apresentar morbi-mortalidade, em ratos.

Descritores: Carboximetilcelulose. Cólon. Cicatrização. Ratos.

\section{Introduction}

Adhesions can be defined as abnormal ligation that becomes established between structures within the body by means of fibrous tissue. They can be classified as congenital or acquired. The development of acquired adhesions is a phenomenon of general response to trauma of the peritoneum, which has an extremely delicate surface, since its cells are weakly connected ${ }^{1}$.

Peritoneal lesions generate a scarring response and lead to the formation of adhesions. These may result from the surgical operation, inflammatory disturbances, infections, neoplastic infiltration, ischemia or irradiation ${ }^{1}$.

Ray et al. ${ }^{2}$ found 303,836 hospitalizations due to procedures related to adhesions during the year 1993. This was equivalent to $1 \%$ of the total number of hospitalizations in the United States, thus implying a high financial cost ${ }^{1}$.

Various prophylactic techniques have been proposed with the aim of diminishing or even eliminating one or more stages of the physiopathological process of adhesion formation ${ }^{3}$. Such techniques have included management of the operative technique, anticoagulation drugs, hormonal and non-hormonal anti-inflammatory drugs, antihistamines, cytostatics, surface separation agents (carboxymethylcellulose and chondroitin sulfate), dextran, Ringer's lactate, proteolytic agents and fibrinolytic agents, among others.

Among the methods for separating injured surfaces using synthetic barriers, the use of Seprafilm ${ }^{\circledR}$ (Genzyme Corporation) has been prominent, because of its promising results. Biochemically, this membrane is composed of sodium hyaluronate and carboxymethylcellulose (SHC), and may be indicated for use in patients who have been submitted to pelvic or abdominal laparotomy, with the objective of assisting in the reduction of the incidence, extent and seriousness of postoperative adhesions. This membrane acts as a temporary, biologically absorbable barrier that separates surfaces that can give rise to adhesion, while the normal healing process takes place ${ }^{3}$.

The property that SHC membrane has for adhering to moist surfaces allows its direct application to tissues with the potential for generating adhesion, before closing up the operative access ${ }^{4}$.

Within approximately 24-48 hours after emplacement, the SHC membrane is transformed into a hydrated gel, thereby providing a protective cover for traumatized tissue. It is slowly reabsorbed by means of phagocytosis ${ }^{4}$. Its components are excreted within 28 days, and there is no need for reoperation to remove it ${ }^{4}$.

Reabsorbable membranes are increasingly utilized by general surgeons and gynecologists with the aim of reducing the formation of postoperative adhesions, although these membranes are not free from complications $^{5}$. Thus, it was decided to verify the concentration of collagen and fibroblasts formed during intestinal suture healing, in an experimental study.

\section{Purpose}

To analyze the effects of sodium hyaluronate and carboxymethylcellulose (SHC) membrane on the formation of collagen and the number of fibroblasts in bowel suture healing in rats.

\section{Methods}

It was utilized forty-eight male Wistar rats (Rattus norvegicus albinus) weighing between 250 and 343g, provided by Federal University of Mato Grosso do Sul.

The proposed study consisted of a comparison between two groups, with and without emplacement of an SHC membrane on the colon of rats that 
underwent bowel suture. Thus, the animals were distributed into two groups: Group I (suture without application of the absorbable membrane) and Group II (suture with application of the absorbable membrane). These were divided into the subgroups 3, 14 and 30, with eight animals in each, which had follow-ups of 3, 14 and 30 days, respectively.

The biologically absorbable membrane Seprafilm ${ }^{\circledR}$ was utilized in the animals of Group II. The membrane is available in individually-wrapped sheets of 12.7 x $15.2 \mathrm{~cm}$, inside a plastic cover and an outer triple-laminated pouch with one sheet of paper on top and one below. It is sterilized by gamma irradiation and packed in card envelopes (Figure 1) that must be stored in environments with a temperature of between $2^{\circ} \mathrm{C}$ and $30^{\circ} \mathrm{C}$, until the expiry date.

The operations were performed in the laboratory of the Discipline of Surgical Technique, of the Department of General Surgery of the UFMS medical course. The animals were subjected to six hours of fasting before the operation, and the procedure was performed under inhaled anesthesia by means of sulfuric ether.

After laparotomy (medial umbilical), a longitudinal incision of $10 \mathrm{~mm}$ in extent was then performed at a distance of $20 \mathrm{~mm}$ distally to the ileocecal valve, at the antimesenteric colonic margin, utilizing a bistoury with blade 15. This was immediately followed by bowel suture with three simple separate stitches using non-absorbable nylon 5-0 thread, in the animals of Group I. In the animals of Group II, the region of the bowel suture was covered with membrane $\left(\right.$ Seprafilm ${ }^{\circledR}$ ) that had previously been cut into rectangular pieces of dimensions $20 \mathrm{~mm}$ x $15 \mathrm{~mm}$, under aseptic conditions.

To make up the wall, polyamide 000 thread was utilized (peritoneum and muscle, separate stitches in U-shape) and 5-0 thread (skin, simple separate stitches).

After the follow-up period established for each subgroup, the animals were then sacrificed by means of inhalation of sulfuric ether, in a closed bell-shaped chamber.

After the death of the animal, the access route to the peritoneal cavity was opened up fully in the form of an inverted "U". Systematic exploration was performed in order to investigate the presence of macroscopic abscesses, dehiscence of the bowel suture and fistulas. The colon segment that underwent the operation was identified and removed as a block of $40 \mathrm{~mm}$ in width (20 $\mathrm{mm}$ to the right and $20 \mathrm{~mm}$ to the left of the center of the incision).

Following this, macroscopic observation of the operative area was performed, with regard to the presence or absence of dehiscence of the wound and secretion.

The histopathological observation was done in the Discipline of Pathological Anatomy, of the Department of General Surgery of the UFMS medical course. The aim was to study the possible morphological alterations (immediate and late-stage) that resulted from the surgical procedure effected. The slides produced were coded, so that the pathologist would not know which specimen was being studied. For quantitative examination of the area of collagen, Masson's trichrome staining was utilized (Figure 2). For counting fibroblasts, hematoxylin-eosin staining was utilized (Figure 3).
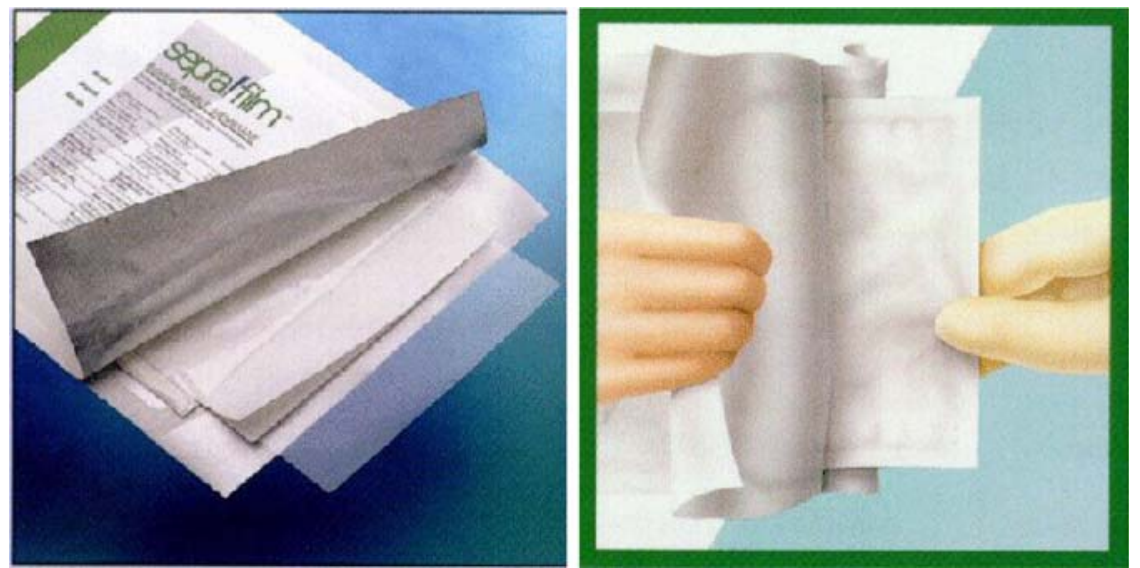

FIGURE 1 - Each biologically absorbable Seprafilm ${ }^{\circledR}$ membrane is individually wrapped and sterilized, and must be handled using dry sterilized gloves. Available from www.genzyme.com 


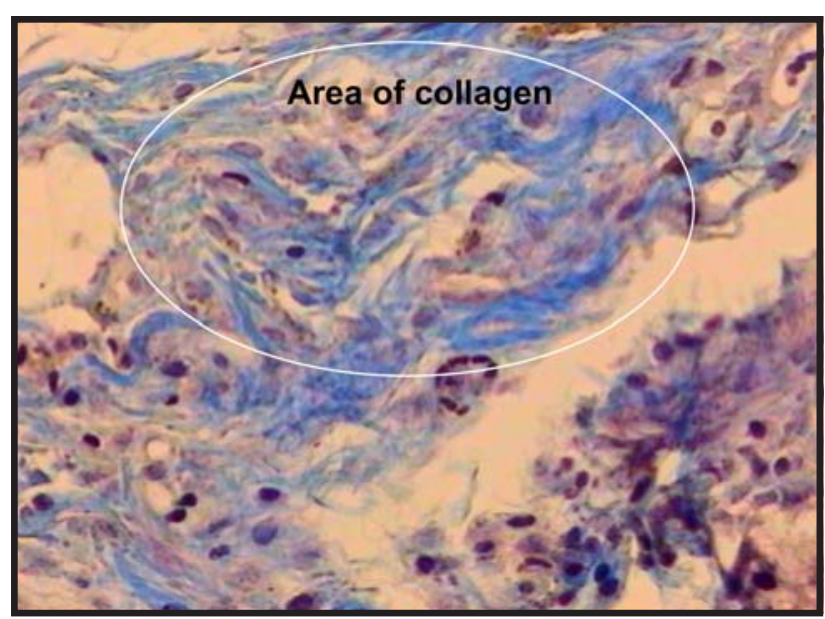

FIGURE 2 - Photomicrograph showing the area of collagen on the colon wall (areas in blue) via Masson's trichrome staining

Image analysis software (ImageLab 2000) was utilized to evaluate the images obtained on the plate. The objective lens of the microscope was standardized at a magnification of 20 times; the maximum intensity of microscope light was utilized; and the distance of the condenser from the slide was $6.5 \mathrm{~cm}$.

The statistical analysis of the results was performed by the Discipline of Biostatistics of the Department of Preventive Medicine, Federal University of São Paulo. For this, parametric and nonparametric tests were applied, taking into account the nature of the variables. The tests applied were: Kruskal-Wallis - with the aim of comparing the three study groups for each variable and each period (3, 14 and 30 days) separately; Mann-Whitney or " $t$ " test for independent groups - for comparing the 3 , 14 and 30-day results for each group; and the Fisher exact or chi-squared test - to compare the percentage frequencies of the macroscopic observations studied. The rejection level for the nullity hypothesis was set at 0.05 or $5 \%$ (a $£ 0.05$ ), and the significant values were indicated using an asterisk.

\section{Results}

No animal died during the experiment and, during the exploration of the peritoneal cavity, no dehiscence or fistula was encountered.

In the comparison within groups, the quantity of collagen in Group I (without membrane) was an average of $23.4 \%, 72.1 \%$ and $67.6 \%$ on the $3^{\text {rd }}, 14^{\text {th }}$ and $30^{\text {th }}$ days, respectively. Kruskal-Wallis variance

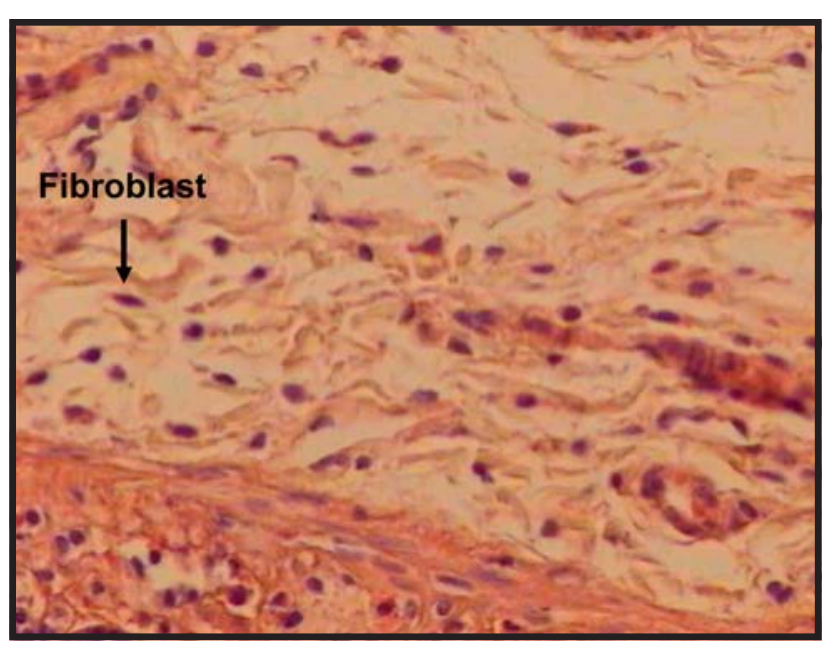

FIGURE 3 - Photomicrograph showing the presence of fibroblasts on the colon wall, utilizing hematoxylin-eosin staining

analysis demonstrated that the 3-day subgroup had less collagen than did the 14-day and 30-day subgroups. In Group II (with membrane), the average quantity of collagen was $22.5 \%, 52.5 \%$ and $51.6 \%$ on the $3^{\text {rd }}, 14^{\text {th }}$ and $30^{\text {th }}$ days, respectively. The same statistical variance analysis demonstrated the same result as in Group I (Figure 4).

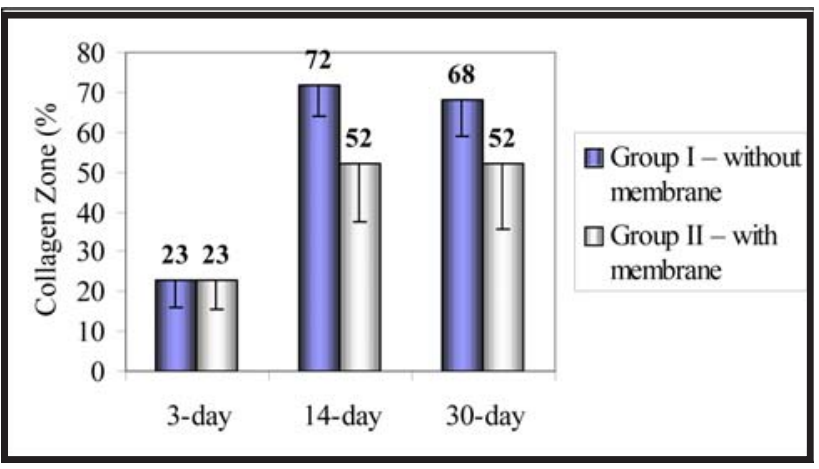

FIGURE 4 - Quantified distribution of the collagen zone (Mean-SD), in percentages, as determined using image analysis software.

In the comparison between groups (Group I and Group II), the Mann-Whitney tests demonstrated that the 14-day subgroups, with a p-value of 0.0013 , rejected the nullity hypothesis, while the 30-day subgroups, with a p-value of 0.0587 , showed a tendency towards rejection. A larger collagen zone was presented in the animals in which the membrane was not used.

In the comparison within groups, the quantity of fibroblasts in Group I (without membrane) was an 
average of 2,13 and 8 on the $3^{\text {rd }}, 14^{\text {th }}$ and $30^{\text {th }}$ days, respectively. Kruskal-Wallis variance analysis with critical $\mathrm{H}$ of 5.99 demonstrated that the 3-day subgroup had smaller numbers than did the 14-day and 30-day subgroups. In Group II (with membrane), the quantity of fibroblasts was an average of 2, 10 and 8 on the $3^{\text {rd }}, 14^{\text {th }}$ and $30^{\text {th }}$ days, respectively. The same statistical variance analysis demonstrated that the 3-day subgroup had smaller numbers than did the 14-day and 30-day subgroups (Figure 5).

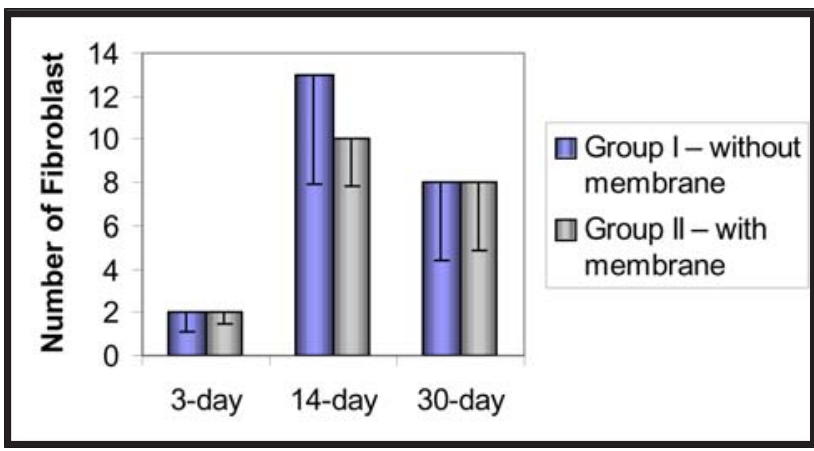

FIGURE 5 - Quantified distribution of fibroblasts (Mean$\mathrm{SD}$ ), in numerical values, as determined using image analysis software.

In the comparison between groups (Group I and Group II), the Mann-Whitney test demonstrated that the 3, 14 and 30-day subgroups had p-values of $1.0000,0.3184$ and 0.5995 , respectively. The nullity hypothesis was not rejected in the groups with and without membrane use.

In this study, when the 3-day subgroups (third postoperative day) with and without membrane use were compared, no statistically significant difference was seen with regard to the quantification of the collagen zone and fibroblasts.

\section{Discussion}

Peritoneal adhesions result from an inflammatory process in the peritoneum when lesions have been caused by harmful stimuli, such as mechanical abrasion, techniques for bringing margins together, tissue ischemia due to devascularization or coagulation, infectious states and reactions to foreign bodies ${ }^{6}$.

Adhesions stimulated by the surgeon or occurring due to trauma, however, may present a protective effect in gastrointestinal anastomoses, as has been demonstrated in the work performed by Biondo-Simões et al. ${ }^{7}$ on rats. In their study, omentoplasty was utilized on colonic anastomoses, thereby improving the healing process because of the neovascularization and increase in the collagen zone.

McLachlin and Delton ${ }^{6}$ followed up the evolution of anastomoses performed in ischemic small intestines in dogs, and observed that the omentum promoted firm adhesions that increased the resistance of the anastomoses by $50 \%$ to $70 \%$, in comparison with the anastomoses of the control group. They concluded that the adhesion produced by the omentum was capable of preventing dehiscence, thereby avoiding the death of the animals.

Katsikas et al. ${ }^{8}$ evaluated the action of the omentum on ischemic jejunal anastomoses in dogs, and observed that, in the group without omentum, the death of all the animals occurred by the fifth postoperative day, as a result of gangrene and peritonitis. However, when the omentum was utilized, it was seen that all the anastomoses were in a good condition, and histological study revealed that there was good irrigation with a contribution from the vessels of the omentum that were directed towards the intestinal wall.

Volpe et al. ${ }^{9}$ evaluated the application of free pieces of mesothelium onto anastomoses of the small intestine in rabbits and observed that there was protection against dehiscence and perforation. However, they reported that the presence of abscesses increased with the use of the pieces.

In a recent study, David et al. ${ }^{5}$ analyzed 1,791 patients with benign diseases of the colon and rectum and concluded that the application of SHC membrane on the intestinal suture could generate dehiscence of anastomoses. This led the authors to advise against the use of such membranes on sutures or anastomoses in patients submitted to colorectal surgery.

Thus, surgeons seek an ideal anti-adhesion product that would be biologically compatible, nonimmunogenic, non-stimulating in relation to infections, efficacious in providing the presence of blood, noninterfering in the healing process and, nowadays, capable of application via a laparoscopic route.

Nonetheless, peritoneal adhesions are the most frequent cause of acute intestinal sub-occlusion and occlusion. These make surgical re-intervention more difficult and troublesome, and produce chronic pelvic 
pains and infertility among women ${ }^{7}$.

It is in the light of this situation, between adhesions that may protect an anastomosis or be the cause of intestinal obstruction or infertility, that greater comprehension of and protective treatment for peritoneal adhesions is sought.

In the present study, the biologically absorbable membrane Seprafilm ${ }^{\circledR}$ was utilized as an anti-adherent method on colonic anastomoses in rats that were studied on the $3^{\text {rd }}, 14^{\text {th }}$ and $30^{\text {th }}$ days after the operation.

The study dates were determined on the basis of the phases of healing (phases I and II) and time required for total degradation of the membrane in the body (28 days).

The organs and anatomical structures inspected in the peritoneal cavity did not present any anatomical variation. The presence of a cecum of large volume is one of the main advantages of utilizing this experimental animal.

At the time of the necropsy on the animals, before collecting the intestinal segment for histopathological analysis, the peritoneal cavity was observed to check for dehiscence of the suture. The fact that there was no dehiscence of the bowel sutures, and that there were no deaths among the animals, even without the use of antibiotics, may be related to the resistance of the rats. Even though these are laboratory animals, their immunological system is well developed.

The sample from each quadrant (total of three) underwent numerical counting of the fibroblasts. These were identified from the histological shape, which does not undergo alterations with the staining that is used. They were counted manually, taking the precaution of having a third person (a pathologist) for verification in the event of doubt. The fact that the counting of fibroblasts was done manually needs to be borne in mind: it could form a source of criticism and error.

Nevertheless, the quantitative measurement of collagen fibers was calculated by the program (ImageLab 2000) in three fields (quadrants), which furnished exact values consisting of the total area covered by structures that were stained blue.

The quantitative histopathological examination for the area of collagen that was performed using image capture equipment and digital processing contributed towards eliminating the subjective element from the pathologist's evaluation. The method proved itself to be efficient and rapid in analyzing known and well- defined variables.

The application of image processing via computer for quantifying variables, as performed in the present study, was utilized by Novelli, Barreto, Matos, Saad and Borra ${ }^{10}$, who showed that the method was efficacious for studies of inflammatory and reparative processes.

The healing can also be evaluated by other means, such as the resistance to tensile force and to rupturing tension ${ }^{11}$. In the present study, however, it was decided only to make a histological investigation of the collagen area and to count the fibroblasts. This required a full sample from the area operated, and this was a limiting factor on the manner of studying the healing of the bowel suture.

Collagen is the agent responsible for the resistance and integrity of all tissues, and the strength and integrity of repair tissue lies in the type and quantity of collagen fiber. The content of collagen furnishes the biochemical basis for changes in tensile strength and rupturing tension ${ }^{8}$.

Another way of investigating the action of collagen in the healing process is to assay the concentration of hydroxyproline, which is an important component of scar tissue. This variable was not included in the present investigation, because it measures the same components of histological investigation as performed in the present research. Thus, it was decided just to make histological observations of the collagen and fibroblasts in the healing process.

The histological findings were compatible with the physiological healing process, through the significant demonstration of the concentration of collagen, since in the later phases (14 and 30 days) there was a greater concentration of collagen fibers, in comparison with the beginning of the process (3 days), with or without the use of the membrane.

In the healing of the intestine, three days after the operation, the slow phase of collagen production is occurring (phase I of the healing). At this stage, the resistance of the wound is provided only by the suture thread ${ }^{12}$. However, the results from the present study, comparing between the groups with and without membrane, showed a significant difference at the 14day and 30-day phases: there was greater concentration of collagen in the animals in which the membrane was not utilized.

Biochemical analysis of normal intestinal wall 
shows that the proportions are: $68 \%$ collagen type I, $20 \%$ type III and $12 \%$ type V. Nonetheless, BiondoSimões et al. ${ }^{7}$ argued that the concentration may not be as important as the organization of the collagen, which is a fundamental element in the quality of tissue healing.

However, the same cannot be said regarding the numbers of fibroblasts, which were not significantly different in the groups with or without membrane. This may be related to the counting method utilized, which may have some influence of subjective analysis.

Is it worth the risk of using the membrane as a means of preventing adhesions from arising in situations in which there are intestinal sutures or anastomoses? This question becomes particularly relevant in surgical situations in which there are potential foci of infection and/or ischemia.

Additional research needs to be stimulated so that responses can be given that are more comprehensive in terms of the interaction with healing provided by the use of an anti-adhesion membrane.

\section{Conclusion}

The utilization of biologically absorbable sodium hyaluronate carboxymethylcellulose(SHC) membrane caused a reduction in the formation of collagen during the healing of bowel sutures, while no morbidity and mortality was observed.

\section{References}

1. Marin BEP. Prevención de adherencias pélvicas postquirúgicas: revisión de tema. Rev Colomb Obstet Ginecol. 2000;51(3):163-7.

2. Ray NF, Denton WG, Thamer M, Henderson SC, Perry S. Abdominal adhesiolysis: in patient care and expenditures in the United States in 1994. J Am Coll Surg. 1998;246:1-
3. Ellis H, Moran BJ, Thompson JN, Parker MC, Wilson MS, Menzies D, McGuire A, Lower AM, Hamtorn RJS, O’Brien F, Buchan S, Crowe AM. Adhesion-related hospital readmissions after abdominal and pelvic surgery: a retrospective cohort study. Lancet. 1999;353:1476-80.

4. Bellón JM, Buján J, Contreras LA, Jurado F. Use of nonporous polytetrafluoroethylene prosthesis in combination with polypropylene prosthetic abdominal wall implants in prevention of peritoneal adhesions. J Biomed Mater Res. 1997;38:197-202.

5. Beck DE, Cohen Z, Fleshman JW, Kaufman HS, van Goor H, Wolff BG; Adhesion Study Group Steering Committee. A prospective randomized, multicenter, controlled study of the safety of Seprafilm ${ }^{\circledR}$ adhesion barrier in abdominopelvic surgery of the intestine. Dis Colon Rectum. 2003;46(10):1310-9.

6. McLachlin A D, Denton D W. Omental protection of intestinal anastomoses. Am J Surg. 1973;125:134-40.

7. Biondo-Simões MLP, Marques LO, Adur RC, Cavazzana W, Lima EB. Sutura x não sutura do peritônio e a formação de aderências: estudo experimental em ratos. Rev Bras Cir. 1996;86(6):303-5.

8. Katsikas D, Sechas M, Antypas G, Floudas P, Moshovos K, Gogas J, Rigas A, Papacharalambous N, Skalkeas G. Beneficial effect of omental wrapping of unsafe intestinal anastomoses. Int Surg. 1977;62:435-7.

9. Volpe M, Costi U, Gianferro A, Albano-Barilli R, Marcone $\mathrm{P}$, Sbordoni L. The use of omental mesh graft to reinforce the intestinal anastomosis: experimental study. Minerva Chir. 1991;46:41-4.

10. Novelli MD, Barreto E, Matos, Saad SS, Borba RC. Aplicação do processamento de imagens por computador na quantificação das variáveis histopatológicas da reparação tecidual de anastomoses colocólicas em cães. Rev Assoc Med Bras. 1992;38:43-4.

11. Tognini JRF. Estudo biomecânico e morfológico da cicatrização da parede abdominal de ratos sob ação de meloxicam [Tese - Mestrado]. Universidade Federal de São Paulo - Escola Paulista de Medicina; 1999.

12. Alatas E, Gunal O, Alatas O, Volak O. Octreotide prevents postoperative adhesion formation by suppressing peritoneal myeloperoxidase activity. Hepatogastroenterology. 2000;47(34): 1034-6.
Correspondence:

Antonio Perez

Rua São Paulo, 68.

79002-270 Campo Grande - MT

acaperez@terra.com.br
Conflict of interest: none Financial source: none

Received: September 4, 2004

Review: October 21, 2004

Accepted: December 19, 2004

How to cite this article:

Perez AC, Matos D, Montero EFS, Souza HS, Barbosa FCP, Saad F, Dip N. Effects of sodium hyaluronate and carboxymethylcellulose membrane on collagen and fibroblast formation in bowel suture healing: experimental study in rats. Acta Cir Bras. [serial online] 2005 Jan-Feb;20(1). Available from URL: http://www.scielo.br/acb

*Color figures available from www.scielo.br/acb 